medRxiv preprint doi: https://doi.org/10.1101/2021.09.25.21262905; this version posted September 28, 2021. The copyright holder for this preprint (which was not certified by peer review) is the author/funder, who has granted medRxiv a license to display the preprint in perpetuity.

All rights reserved. No reuse allowed without permission.

\title{
Discovering disease-causing pathogens in resource-scarce Southeast Asia using a global
} metagenomic pathogen monitoring system

Jennifer A. Bohl' ${ }^{1}$, Sreyngim Lay ${ }^{2,3}$, Sophana Chea ${ }^{2,3}$, Vida Ahyong ${ }^{4}$, Daniel M. Parker ${ }^{5}$, Shannon Gallagher $^{6}$, Jonathan Fintzi ${ }^{6}$, Somnang Man ${ }^{2,3}$, Aiyana Ponce ${ }^{1}$, Sokunthea Sreng ${ }^{2,3}$, Dara Kong ${ }^{2,3}$, Fabiano Oliveira ${ }^{1}$, Katrina Kalantar ${ }^{8}$, Michelle Tan $^{4}$, Liz Fahsbender ${ }^{8}$, Jonathan Sheu ${ }^{8}$, Norma Neff ${ }^{4}$, Angela M. Detweiler ${ }^{4}$, Sokna Ly ${ }^{2,3}$, Rathanak Sath ${ }^{2,9}$, Chea Huch ${ }^{3}$, Hok Kry ${ }^{9}$, Rithea Leang ${ }^{3}$, Rekol Huy ${ }^{3}$, Chanthap Lon ${ }^{2,3}$, Cristina M. Tato ${ }^{4}$, Joseph L. DeRisi ${ }^{4,10}$, Jessica E. Manning ${ }^{1,2}$

1 - Laboratory of Malaria and Vector Research, National Institute of Allergy and Infectious Diseases, National Institutes of Health, Bethesda, Maryland, USA

2 - International Center of Excellence in Research, National Institute of Allergy and Infectious Diseases, National Institutes of Health, Phnom Penh, Cambodia

3 - National Center for Parasitology, Entomology, and Malaria Control, Ministry of Health, Phnom Penh, Cambodia

4 - Chan Zuckerberg Biohub, San Francisco, California, USA

5 - University of California, Irvine, California USA

6- Biostatistics Research Branch, National Institute of Allergy and Infectious Diseases, National Institutes of Health, Bethesda, Maryland, USA

8 - Chan Zuckerberg Initiative, Redwood City, California, USA

9 - Kampong Speu District Referral Hospital, Chbar Mon, Cambodia

10 - University of California, San Francisco, California USA

${ }^{*}$ Corresponding Author: Jennifer A. Bohl

Email: bohlja@nih.gov

Author Contributions: J.A.B, J.E.M, D.M.P, V.A., S.C., S.L., and J.L.D. designed the research; J.A.B, S.L., S.P., V.A., D.P., S.M., A.P., S.S., D.K., F.O., S.L., R.S., C.H., H.K., R.L., R.H., C.L. and J.L.D. performed research; J.A.B, S.L., S.C., V.A., J.E.M., D.A., S.G., J.F., K.K., M.T., L.F., J.S., N.N., A.D., C.T., J.L.D., contributed analytical tools and analyzed the data, and J.A.B, J.E.M, and J.L.D wrote the paper. All authors report no potential conflicts of interest.

Competing Interest Statement: We have no competing interests.

Classification: Biological Sciences; microbiology; medical sciences 
medRxiv preprint doi: https://doi.org/10.1101/2021.09.25.21262905; this version posted September 28, 2021. The copyright holder for this preprint (which was not certified by peer review) is the author/funder, who has granted medRxiv a license to display the preprint in perpetuity. All rights reserved. No reuse allowed without permission.

36 Keywords: metagenomics; vector-borne disease; next generation sequencing; surveillance; Southeast

37 Asia

38

\section{Significance Statement:}

Metagenomic pathogen sequencing offers an unbiased approach to characterizing febrile illness. In resource-scarce settings with high biodiversity, it is critical to identify disease-causing pathogens in order to understand burden and to prioritize efforts for control. Here, mNGS characterization of the pathogen landscape in Cambodia revealed diverse vector-borne and zoonotic pathogens irrespective of age and gender as risk factors. Identification of key pathogens led to changes in national program surveillance. This study provides a recent 'real world' example for the use of mNGS surveillance in both identifying diverse microbial landscapes and detecting outbreaks of vector-borne, zoonotic, and other emerging pathogens in resource-scarce settings.

This PDF file includes:

Main Text

Figures 1 to 4

53

Tables 1 to 2

54 
medRxiv preprint doi: https://doi.org/10.1101/2021.09.25.21262905; this version posted September 28, 2021. The copyright holder for this preprint (which was not certified by peer review) is the author/funder, who has granted medRxiv a license to display the preprint in perpetuity.

\section{Abstract}

56 Understanding the regional pathogen landscape and surveillance of emerging pathogens is key to

57 mitigating epidemics. Challenges lie in resource-scarce settings, where outbreaks are likely to emerge,

58 but where laboratory diagnostics and bioinformatics capacity are limited. Using unbiased metagenomic

59 next generation sequencing (mNGS), we identified a variety of vector-borne, zoonotic and emerging

60 pathogens responsible for undifferentiated fevers in a peri-urban population in Cambodia. From March

612019 to October 2020, we enrolled 473 febrile patients aged 6 months to 65 years of age presenting to a

62 large peri-urban hospital in Cambodia. We collected sera and prepared sequencing libraries from

63 extracted pathogen RNA for unbiased metagenomic sequencing and subsequent bioinformatic analysis

64 on the global cloud-based platform, IDseq. We employed multivariate Bayesian models to evaluate

65 specific pathogen risk causing undifferentiated febrile illness. mNGS identified vector-borne pathogens as

66 the largest clinical category with dengue virus (124/489) as the most abundant pathogen.

67 Underappreciated zoonotic pathogens such as Plasmodium knowlesi, leptospirosis, and co-infecting HIV

68 were also detected. Early detection of chikungunya virus presaged a larger national outbreak of more

69 than 6,000 cases. Pathogen-agnostic mNGS investigation of febrile persons in resource-scarce

70 Southeast Asia is feasible and revealing of a diverse pathogen landscape. Coordinated and ongoing

71 unbiased mNGS pathogen surveillance can better identify the breadth of endemic, zoonotic or emerging

72 pathogens and deployment of rapid public health response.

74 Clinical Trial Numbers: NCT04034264 and NCT03534245.

\section{Significance Statement}

77 Public health authorities recently advocated for global expansion of sequencing capacity worldwide;

78 however, the importance of genomics-based surveillance to detect emerging pathogens or variants in 79 resource-limited settings is paramount, especially in a populous, biodiverse Southeast Asia. From 2019

80 to 2020, pathogen metagenomic next generation sequencing (mNGS) of febrile patients in Cambodia

81 identified several vector-borne and zoonotic pathogens, both common and underappreciated, and

82 resulted in a variety of actionable health interventions. Understanding these pathogen discoveries, and

83 the attendant challenges of mNGS in these outbreak-prone settings, is critical for today's global society

84 and decision-makers in order to implement sequencing-based pathogen or variant detection.

85

86 
medRxiv preprint doi: https://doi.org/10.1101/2021.09.25.21262905; this version posted September 28, 2021. The copyright holder for this preprint (which was not certified by peer review) is the author/funder, who has granted medRxiv a license to display the preprint in perpetuity.

All rights reserved. No reuse allowed without permission.

\section{Main Text}

\section{Introduction}

89 A global pathogen surveillance network can best identify emerging and underlying pathogens if it employs

90 pathogen-agnostic detection methods, such as metagenomic next-generation sequencing (mNGS), and is

91 decentralized to include low-resource settings that are often biodiversity hotspots at increased risk for

92 disease outbreaks (1-3). Lack of diagnostics in these areas makes undifferentiated febrile illnesses

93 difficult to diagnose and treat, much less confirm and report for global public health awareness. In

94 Southeast Asia where a quarter of the world's population resides, rapid but heterogeneous economic

95 development juxtaposes low-resource and high-resource areas, causing high cross-border mobility of

96 persons for economic opportunities. In Cambodia and Laos, laboratory testing for non-malarial fevers is

97 limited, particularly in rural and peri-urban areas where simple diagnostics like dengue rapid tests may not

98 be available (4). In many instances, healthcare providers make diagnoses and empiric treatment

99 decisions based on symptoms so the responsible pathogen is rarely identified.

100 Syndromic diagnosis is an epidemiological pitfall in Southeast Asia because the true scope of pathogen

101 diversity remains poorly defined. From limited decade-old surveillance data of febrile Cambodians,

102 Plasmodium infections made up more than $50 \%$ of the responsible pathogens followed by

103 pathogenic Leptospira (9.4\%), influenza virus (8.9\%), and dengue virus (DENV)(6.3\%) (5). In a separate

104 serosurvey, one third of febrile Cambodian patients had antibodies to rickettsiae that cause scrub typhus

105 (via chiggers containing Orientia tsutsugamushi), endemic typhus (via rat fleas Xenopsylla cheopia

106 carrying Rickettsia typhi), spotted fever (via ticks carrying Rickettsia rickettsii), and murine typhus (via cat

107 fleas Ctenocephalides felis carrying Rickettsia felis), which some speculate may be the next mosquito-

108 borne outbreak $(6,7)$. Entomological studies of field-collected ticks, mosquitos and fleas in Cambodia

109 have revealed high biodiversity of potential disease-carrying vectors including underappreciated

110 Bartonella spp $(8,9)$. Other serosurveys of bats, domestic pigs, and birds in Cambodia demonstrated the

111 presence of antibodies to other zoonotic viruses including Nipah virus, hepatitis E, Japanese encephalitis

112 virus, and West Nile virus with potential for spillover into the human population (10-12).

113 In these settings of high pathogen diversity, monitoring with pathogen-agnostic tools, such as mNGS, is

114 ideal but typically not available in-country to provide results within an actionable timeframe. Examples of 
medRxiv preprint doi: https://doi.org/10.1101/2021.09.25.21262905; this version posted September 28, 2021. The copyright holder for this preprint (which was not certified by peer review) is the author/funder, who has granted medRxiv a license to display the preprint in perpetuity.

All rights reserved. No reuse allowed without permission.

115 mNGS identifying pathogens in patients are limited to clinical research programs in developed countries

116 (13-15). However, it is clear that broadly applied and timely mNGS in any population can lead to a better

117 understanding of the overall pathogen landscape, which has direct implications for disease containment

118 methods in the event of an outbreak $(16,17)$. Here, as an initial step in a low-resource setting in Asia, we

119 describe implementation of mNGS serosurveillance, using an open-source cloud-based bioinformatics

120 tool, to identify pathogens in sera from febrile individuals in peri-urban Cambodia.

121

122 Results

\section{Clinical characteristics of febrile participants in Cambodia}

124 From March 2019 to October 2020, a total of 487 patients presenting with fever were screened, enrolled

125 and contributed sera for mNGS (377 patients in hospital-based cohort and 110 in community-based

126 cohort) (Figure 1). Demographic and clinical characteristics are detailed in Table 1; notably, the

127 participants are young with the median age in the hospital cohort at 10 years (IQR 12), and 6 years (IQR

1284 4) in the community cohort. The predominant symptom reported in both studies was headache $52.4 \%$

129 (256/487). Of the adults, 67.7\% (61/90) were employed in non-agricultural settings while the remainder

130 were farmers or unemployed. In only the hospital cohort, approximately half of participants reported insect

131 exposure, primarily mosquitos (211/376). Nearly three-quarters of participants reported animal exposure

132 (275/376). The most common animal exposures included dogs, cats, and chickens, with some rare

133 reports of exposure to pigs and horses.

134 
135 Figure 1.

136

137

138

139

140

141

142

143

144

145

146

147

148

149

150

151

152

153

154

155

156

157

158

159

160

161

162

163

\section{COMMUNITY}

771 children screened and enrolled in longitudinal community-based study in 2018

110 provided sera in 2019

23 afebrile children (controls)

87 febrile children presenting for sick visits

112 sera sequenced on NovaSeq6000

*2 patients had 2 febrile visits each

196 samples with detectable pathogen

295 samples with no

detectable pathogen

94 on NovaSeq6000

283 on Iseq 100

\begin{tabular}{|c|c|}
39 unable to be validated & 3
\end{tabular}

12 inadequate sample type

27 unavailability of pathogen-specific

clinical diagnostic testing

Figure 1. Study flow chart. Flow of enrolled febrile patients through two clinical studies defined as hospital (cross-sectional febrile patient hospital-based cohort) and community (longitudinal pediatric community-based cohort). 
medRxiv preprint doi: https://doi.org/10.1101/2021.09.25.21262905; this version posted September 28, 2021. The copyright holder for this preprint (which was not certified by peer review) is the author/funder, who has granted medRxiv a license to display the preprint in perpetuity.

Table 1. Baseline demographic and clinical characteristics of cohort

\section{Characteristic}

$\mathrm{n}$

Male

Age - years (median, IQR)

Year of fever

2019

Attends school

Attends work

\section{Socioeconomic status}

Very poor

Lower

Middle

Upper

\section{Risk factors}

Coil use (yes)

Insecticide use (yes)

Larvicide use (yes)

Net use (yes)

Animal contact (yes)

Insect contact (yes) ${ }^{\dagger}$

\section{Symptoms}

\section{Aching}

Chills

Cough

Headache

Joint pain

Mouth sores

Muscle pain

Runny nose

Heart palpitations

Rash

\section{Clinical laboratory data}

$\mathrm{n}$

WBC $\left(10^{12} / L\right)$, median, IQR

Lymphocyte \%, median, IQR

Neutrophil \%, median, IQR

Platelets $\left(10^{y} / \mathrm{L}\right)$, median, IQR

\section{Hospital}

377

207, 54.9

10,12

$196,52.0$

$146,38.8$

$75,19.9$

\section{Community}

110

$56,50.9$

6,4

$110,100.0$
$64,58.2$
$0,0.0$

$0,0.0$

$22,20.0$

$88,80.0$

0,0

$70,63.6$
$60,54.5$
$27,24.5$
$99,90.0$
N/A
N/A

$225,59.8$

$191,50.8$

$28,7.4$

$313,83.2$

$275,73.1$

$211,56.1$
131, 34.7

$167,44.3$

$175,46.4$

236, 62.6

$\mathrm{N} / \mathrm{A}$

88, 23.3

$\mathrm{N} / \mathrm{A}$

66, 17.5

$120,31.8$

$81,21.5$

Hospital

137

$7,5.6$

30,20

70,30

209, 140
N/A

$\mathrm{N} / \mathrm{A}$

$\mathrm{N} / \mathrm{A}$

20, 17.9

1, 0.9

N/A

4, 3.6

N/A

$\mathrm{N} / \mathrm{A}$

$0,0.0$

Community

65

$6.8,5.6$

20, 20

70,20

250, 115.5
Total

487

263, 54.0

8, 10

306, 62.8

210, 43.2

75, 15.4

$16,3.3$

200, 41.2

269, 55.3

$1,0.2$
166

167

168

169

170

171

172

173

These data are in $\mathrm{n}, \%$ unless otherwise stated

${ }^{\dagger}$ This question was specifically asked in the hospital study questionnaire but not in the community study questionnaire.

\#23 patients from Community Study did not have symptoms.

${ }^{+}$Not all patients had complete blood counts because study physician decided based on clinical necessity. 
medRxiv preprint doi: https://doi.org/10.1101/2021.09.25.21262905; this version posted September 28, 2021. The copyright holder for this preprint (which was not certified by peer review) is the author/funder, who has granted medRxiv a license to display the preprint in perpetuity.

All rights reserved. No reuse allowed without permission.

\section{mNGS Characterization of the Pathogen Landscape in Febrile Cambodians}

176 The composite of identified pathogens in both cohorts is shown in Figure 2. Vector-borne disease was

177 the most prevalent clinical category for mNGS analysis of sera from febrile patients. This clinical category

178 included DENV (138/489), most abundant, followed by rickettsiae (13/489), CHIKV (10/489) and $P$. vivax

179 (6/489). The second highest clinical category was systemic viral illness notably including hepatitis and

180 pegiviruses (8/489).

181

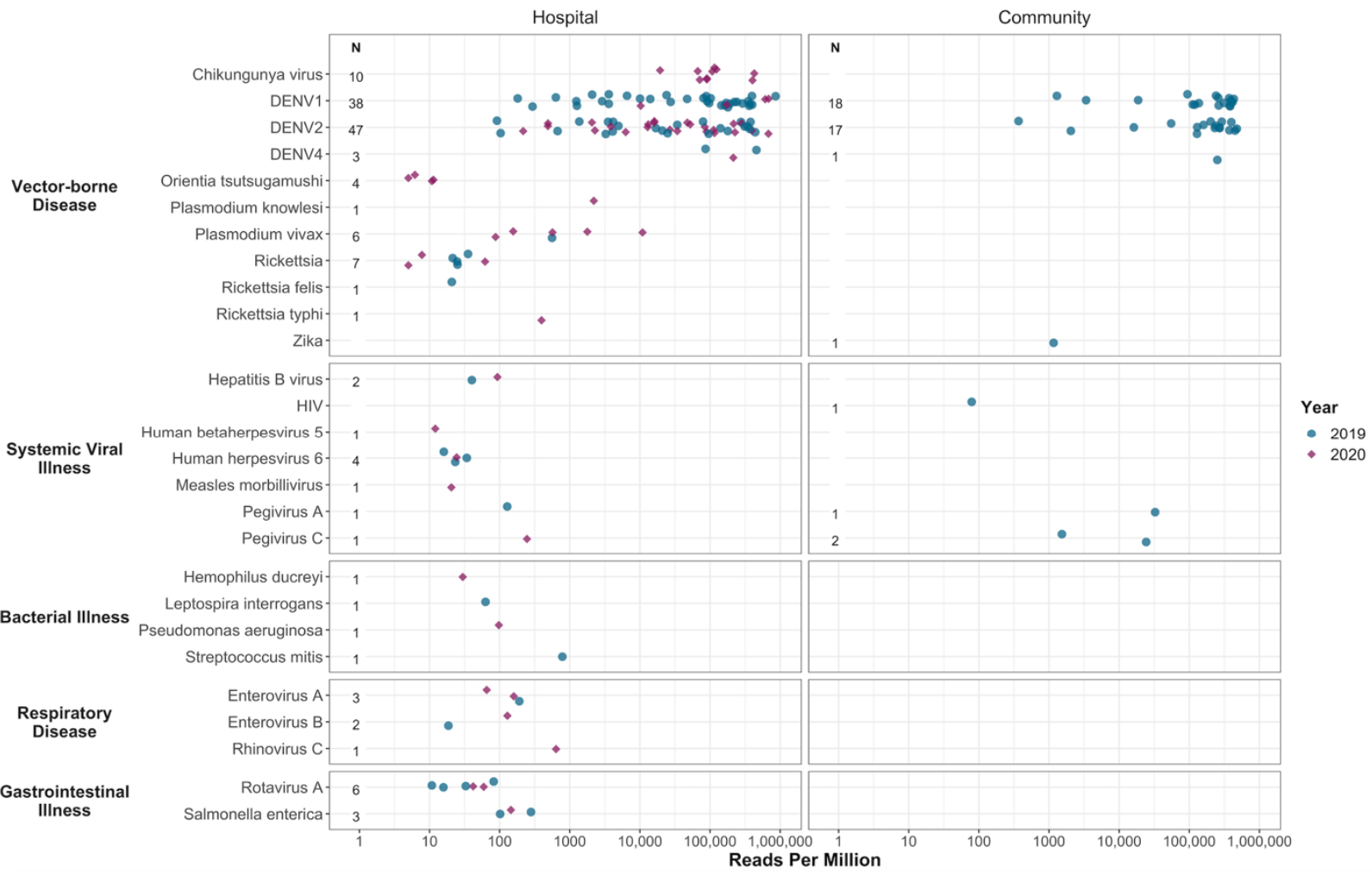

183

184

185

186

187

188

\section{Pathogen Serosurveillance Findings in Clinical and Regional Contexts}

190 Here, we describe select pathogens in greater detail pertinent to clinical and genomic epidemiology of the

191 Southeast Asian region.

192
Figure 2. Microbial landscape identified from serum samples of febrile Cambodian participants. Identified pathogens in sera by clinical category, reads per million, and study setting. Each circle represents a pathogen in 2019 and each diamond a pathogen in 2020. 
medRxiv preprint doi: https://doi.org/10.1101/2021.09.25.21262905; this version posted September 28, 2021. The copyright holder for this preprint (which was not certified by peer review) is the author/funder, who has granted medRxiv a license to display the preprint in perpetuity.

194 Dengue was responsible for the greatest disease burden in our study (138 DENV positive cases of 489

195 febrile cases) due to the largest DENV outbreak documented in Cambodian history in 2019. The

196 predominant DENV serotype of the outbreak in Kampong Speu province was DENV1 (Supplemental

197 Table 2). 71\% (48/67) of DENV1 sequences identified, aligned to DENV1, accession no. MF033254.1

198 from 2016 DENV1 outbreak in Singapore. Phylodynamic analyses will be presented elsewhere.

$200 \quad$ Rickettsia

201 While rickettsial diseases are easily treated with oral doxycycline, the challenge is timely diagnosis and

202 access to serological and/or molecular testing for confirmation. In Laos, a country of similar climate and

203 socio-economic status as Cambodia, 7\% (122/1871) of febrile patients were positive for scrub typhus, $1 \%$

204 murine typhus (10/1849) and 1\% undetermined Rickettsia spp. combined with Rickettsia felis (9/1849)

205 (21). Here, four patients were positive for Orientia tsutsugamushi, highly homologous to accession no.

206 CP044031.1 from Zhejiang province, China and to accession no. LS398552.1 from Udon Thani, Thailand

207 (22). mNGS identified one case of Rickettsia felis, one of Rickettsia typhi and seven cases of the genus

208 Rickettsia without clinical confirmation of species-level data.

210 Chikungunya virus

211 In July 2020, we identified 10 cases of CHIKV in Kampong Speu Province where patients presented with

212 symptoms of fever, rash, shaking chills and arthralgias. mNGS analysis revealed CHIKV as the clinical

213 etiology after initial diagnoses of DENV were made based on patients' presenting symptoms. These

214 sequences aligned closely with three Urban Asian Lineage (AUL) sequences from Thailand (accession

215 nos. MN075149.1, MN630017.1 and MK468801.1). CHIKV PCR was then added to national surveillance

216 and it was noted that the outbreak spread rapidly to 21 other provinces in Cambodia, affecting at least

2176,000 people by the end of September 2020 despite implementation of vector control (23).

219 Zika virus 
medRxiv preprint doi: https://doi.org/10.1101/2021.09.25.21262905; this version posted September 28, 2021. The copyright holder for this preprint (which was not certified by peer review) is the author/funder, who has granted medRxiv a license to display the preprint in perpetuity.

All rights reserved. No reuse allowed without permission.

220 ZIKV circulates at low levels in Thailand and Vietnam, however almost no active cases have been

221 reported in Laos and Cambodia even during the global epidemic in 2015-16.(24, 25) Since 2010, only one

222 prospective case of active ZIKV infection was detected in Cambodia, notably Kampong Speu

223 province.(26) In the current study, sera from an otherwise asymptomatic school-aged female was

224 positive for ZIKV with $20.1 \times$ coverage depth and $98.8 \%$ coverage breadth closely aligned with to

225 accession no. MF996804.1, a Thai case of microcephaly, with $99.2 \%$ sequence similarity. These

226 information indicate that ZIKV in Cambodia has regional sequence similarities to Thailand, possibly

227 related to high cross-border traffic between the two countries despite little ZIKV detected in

228 Cambodia.(27) Another possibility is a separate enzootic ZIKV transmission cycle maintained in non-

229 human primates given recent evidence of ZIKV in stump-tailed macaques in Thailand (28).

231 Plasmodium spp.

232 Cambodia is in the pre-elimination stage for all malarial species with a specific goal to eliminate $P$.

233 falciparum by 2025 (29). mNGS identified six cases of very low parasitemia (down to 16 parasites per uL)

234 with $P$. vivax, initially missed on microscopy or rapid test. $P$. vivax has replaced $P$. falciparum as the most

235 prevalent form of malaria in Southeast Asia, particularly in Cambodia where eradicative liver-stage

236 treatment of $P$. vivax with primaquine has not yet been widely adopted (4). mNGS also identified $P$.

237 knowlesi in a forest worker, previously diagnosed with $P$. malariae using blood smear microscopy. This

238 pathogen identification led to retrospective mNGS assessment of other $P$. malariae cases and the

239 addition of $P$. knowlesi PCR to national surveillance. Given human encroachment and deforestation in

240 Southeast Asia, there is ample opportunity for spread of zoonotic malaria, such as $P$. knowlesi typically

241 found in non-human primates, that may endanger elimination goals (4).

243 Leptospira interrogans

244 Leptospirosis is an underappreciated health threat in Southeast Asia. In nearby Kampong Cham

245 province, $2.5 \%(17 / 630)$ of all fevers in 27 rural to semi-rural villages were confirmed as acute

246 leptospirosis infection via IgM serology and microagglutination testing (30). In November 2019, a school-

247 aged female with a fever of $38.5^{\circ} \mathrm{C}$ presented with a headache and abdominal pain. mNGS identified 
medRxiv preprint doi: https://doi.org/10.1101/2021.09.25.21262905; this version posted September 28, 2021. The copyright holder for this preprint (which was not certified by peer review) is the author/funder, who has granted medRxiv a license to display the preprint in perpetuity.

All rights reserved. No reuse allowed without permission.

248 Leptospira interrogans at $62.9 \mathrm{rpM}$ with $99.7 \%$ homology to CP048830.1. Due to limited in-country

249 diagnostic testing, no further testing was performed, but clinical examination confirmed the presence of

250 conjunctival effusion, a specific feature of leptospirosis.

$252 \quad$ HIV-1 and DENV co-infection

253 A school-aged female of Vietnamese descent presented to the hospital with a $39^{\circ} \mathrm{C}$ fever and mNGS

254 analysis revealed a possible coinfection of DENV2 and HIV. The low sequence coverage (14\%) of a

255 Vietnamese HIV genome, accession no. FJ185253.1, was likely due to the sequencing space used on the

256 high number of DENV2 reads (DENV2: 368 rpM, 99\% sequence coverage breadth and 17.1x depth

257 versus HIV: $78.1 \mathrm{rpM}, 14 \%$ coverage and 1x depth) for this sample (31). However, re-mapping all reads

258 belonging to the Lentivirus genus resulted in a more comprehensive assessment with $33 \%$ coverage of

259 the Vietnamese HIV-1 viral genome (accession no. FJ185246. 1) at a depth of 3.47x, with greatest

260 homology to a Thai HIV-1 strain, accession no. LC114832.1, from a female sex worker. The mNGS

261 results were confirmed by clinically validated HIV 1/2 antibody tests, and the patient subsequently

262 initiated antiretroviral therapy.

264 Risk modeling of contracting vector-borne disease

265 The probability of having a vector-borne infection was increased for individuals in the hospital study if the

266 household owned a car, (OR 1.95, 95\% 1.19-3.21) or if they were 5 to 18 years of age (for 5 to 10 years

267 of age; OR 2.35, 95\% Cl (1.11-5.06); OR 2.68 for 10 to 18 years of age; $1.4-5.29)$ (Figure 3; Table 2). In

268 the community cohort, living near surface flooding, using a Scaled Flooding Index (4-week lag),

269 significantly increased the likelihood of vector-borne infection (OR 2.04, 95\% Cl 1.24-3.49) while larvicide

270 use decreased the chances of acquiring a vector-borne disease (OR $0.3295 \% \mathrm{Cl} 0.11-0.8$ ). 


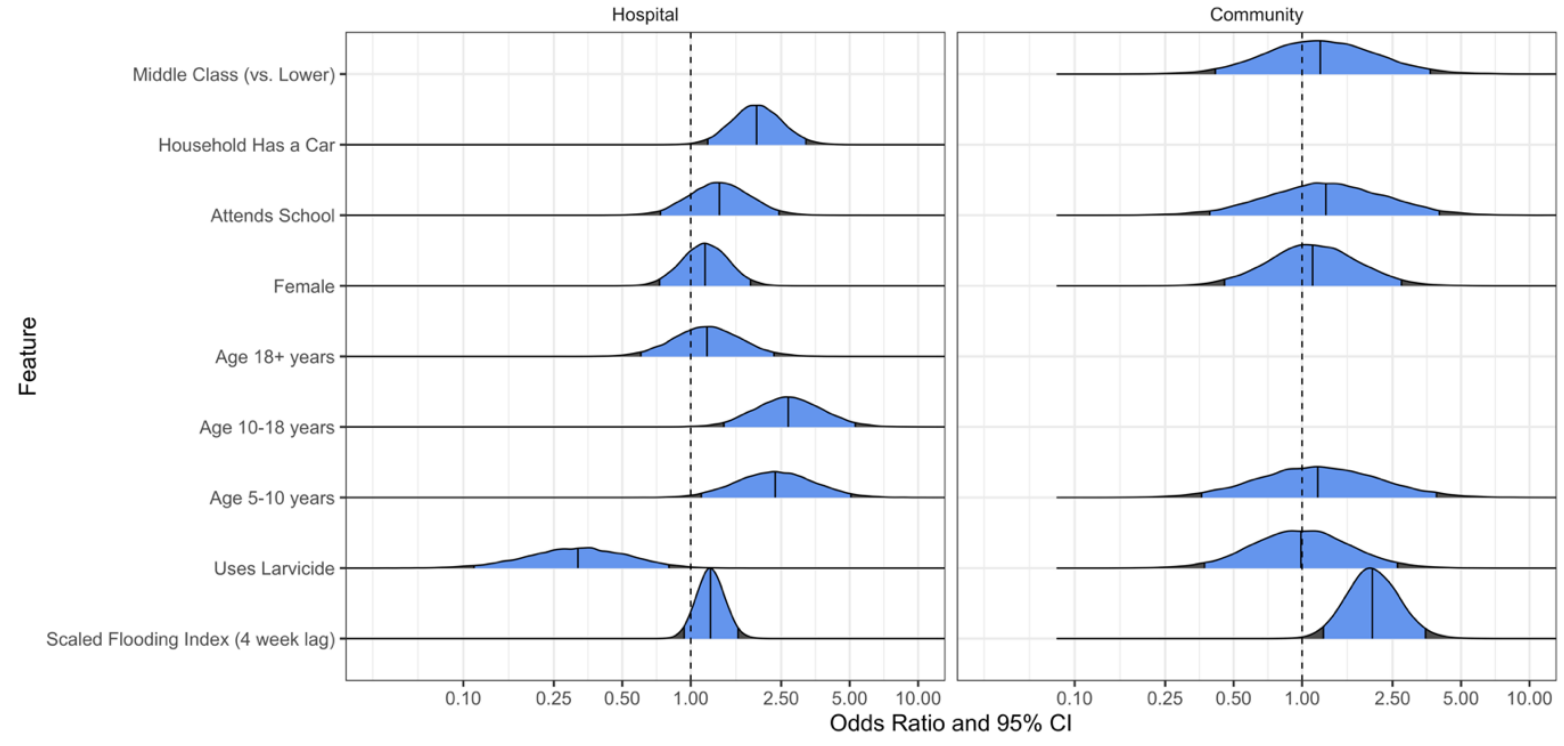

273 Figure 3. Probability of infection by vector-borne pathogen. Results of multivariate analyses in both

276 Table 2. Predictors for infection by vector borne versus non-vector-borne pathogens

Risk Factors

Scaled flooding index

Uses larvicide

$$
\text { Community } 2.04
$$$$
\text { Hospital } 1.22
$$

Age 5-10 years

$$
\text { Hospital } 0.32
$$$$
\text { Community } 0.99
$$

Hospital 2.35

Community 1.17

Age 10-18 years

Hospital 2.68

$$
\text { Community N/A }
$$

Age $18+$ years

\section{Female}

Hospital 1.18

$$
\text { Community N/A }
$$

Attends school

$$
\text { Hospital } 1.16
$$

$$
\text { Community } 1.11
$$

Household has a car

$$
\text { Hospital } 1.34
$$$$
\text { Community } 1.27
$$

Middle class (vs. lower)

$$
\text { Community N/A }
$$

$$
\begin{aligned}
\text { Hospital } & \mathrm{N} / \mathrm{A} \\
\text { Community } & 1.2
\end{aligned}
$$

\section{$95 \% \mathrm{Cl}$}

$0.94-1.61$

1.24-3.49

$0.11-0.8$

$0.37-2.63$

1.11-5.06

0.36-3.9

1.4-5.29

$\mathrm{N} / \mathrm{A}$

0.6-2.32

$\mathrm{N} / \mathrm{A}$

$0.73-1.83$

$0.46-2.74$

$0.74-2.44$

$0.39-4.02$

1.19-3.21

$\mathrm{N} / \mathrm{A}$

N/A

0.42-3.66 
medRxiv preprint doi: https://doi.org/10.1101/2021.09.25.21262905; this version posted September 28, 2021. The copyright holder for this preprint (which was not certified by peer review) is the author/funder, who has granted medRxiv a license to display the preprint in perpetuity.

All rights reserved. No reuse allowed without permission.

277 Crop land was the predominant land cover type for participants' homes (89\%; 426/476; Figure 4) with

278 urban as the next most common (10\%; 49/476). Urban participants were more likely to have non-vector

279 borne diseases (13\%; 4/30) than vector-borne pathogens $(9 \% ; 15 / 162)$; however, there were still

280 participants from primarily urban areas with CHIK, DENV1, DENV2, or ZIKV infections (Supplemental

281 Table 1). Interestingly, 92\% (125/135) of DENV cases were from crop land (Supplemental Table 2).

282 Formal analyses by each disease outcome were not pursued because of small overall counts.

283 Exploratory univariate analysis of the Els indicated that only the surface flooding index was associated

284 with any of the disease outcomes (Figure S1).

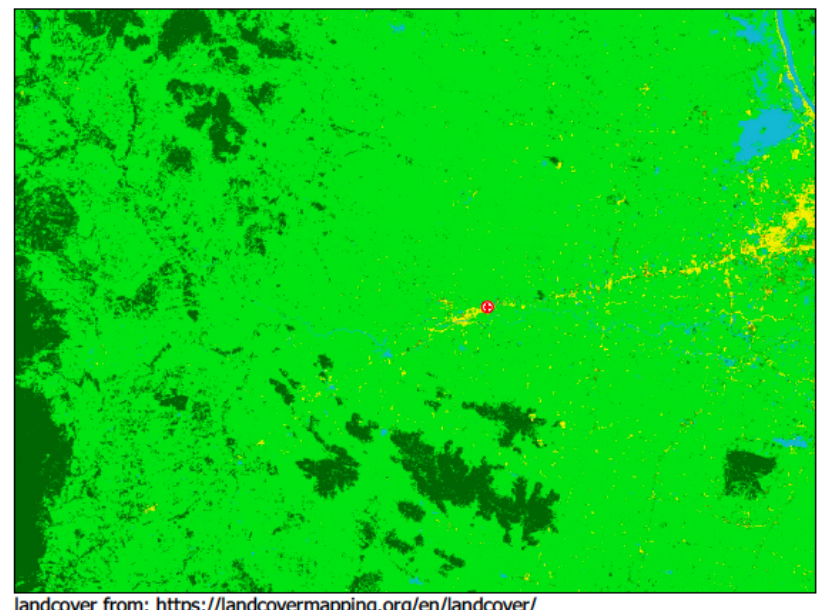

andcover from: https://landcovermapping org/en/landcover/

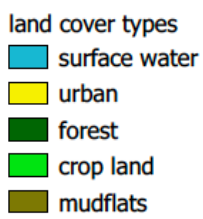

() Chbar Mon referral hospital

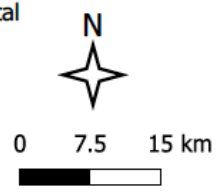

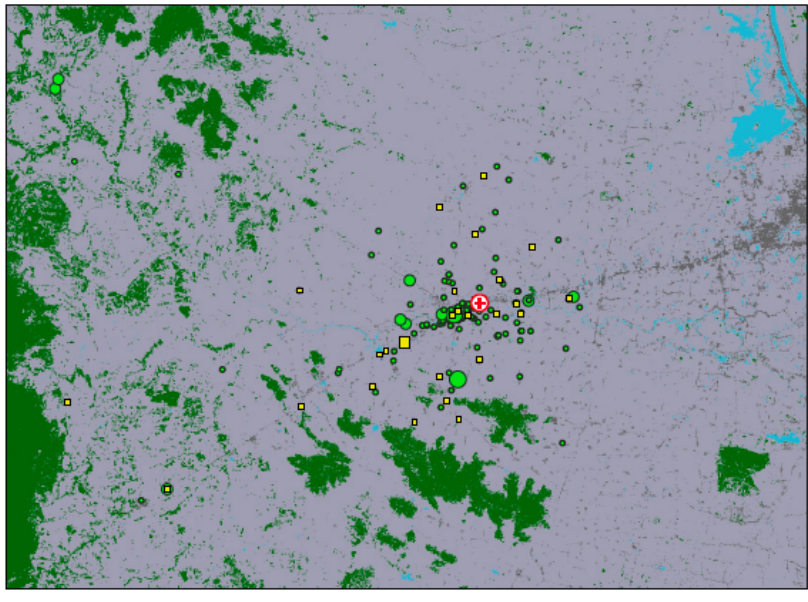

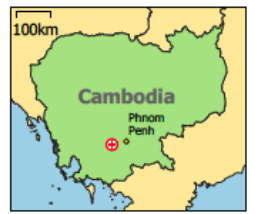

non vector-borne vector-borne infections infections

- 1 - 1

ㅁ 2 - $2-3$

$\square 30 \quad 4-5$

Figure 4. Study site and land use map. Patient locations classified by land use and vector-borne disease

290 Discussion

291 Metagenomic NGS serosurveillance from peri-urban Cambodia revealed a diverse pathogen landscape,

292 rich in underappreciated vector-borne and zoonotic pathogens, responsible for febrile disease. In this

293 prospective, cross-sectional mNGS study, we identified common and confounding pathogens and

294 demonstrated the feasibility and usefulness of a decentralized metagenomic sequencing pipeline. Despite

295 challenges of actionable mNGS surveillance in a resource-scarce settings, we contributed to genomics- 
medRxiv preprint doi: https://doi.org/10.1101/2021.09.25.21262905; this version posted September 28, 2021. The copyright holder for this preprint (which was not certified by peer review) is the author/funder, who has granted medRxiv a license to display the preprint in perpetuity.

All rights reserved. No reuse allowed without permission.

296 informed pathogen epidemiology that is otherwise lacking in Cambodia and other similar settings, yet

297 globally relevant given major demographic and socioeconomic shifts underway in the region that may

298 increase the likelihood for disease epidemics $(4,32)$.

299 Our study provides a more granular analysis of changing pathogen dynamics than prior surveillance with

300 pre-determined targeted diagnostics like PCR $(5,33,34)$. The hierarchy of species abundance identified

301 here is likely attributed to current malaria elimination campaigns, heterogenous socioeconomic

302 development, and increased human migration (4, 35). DENV is now the most prevalent pathogen,

303 particularly in children in comparison to neighboring countries, while malaria makes up a less substantial

304 portion of febrile cases than in prior years where PCR-confirmed malaria infections was as high as $51.1 \%$

305 (754/1475) of febrile individuals presenting to peri-urban hospitals $(5,32)$.

306 Over the past two decades, the importance of vector-borne pathogens as drivers of epidemics and as

307 emerging pathogens cannot be discounted despite current threats posed by novel respiratory pathogens.

308 The detection of primarily vector-borne pathogens in this study is relevant as genomic surveillance

309 becomes the foundation of global health security. The Asian strain of ZIKV evolved to enhance infectivity

310 of humans and mosquitos via a single alanine-to-valine substitution that increased NS1 antigenemia,

311 ultimately resulting in epidemics as early as 2007 in Micronesia and later in the Americas linked to

312 microcephaly (36). Prior CHIK outbreaks were traced to a single mutation in 2005 allowing increased

313 fitness of CHIK in Aedes albopictus mosquitos, and thus conferring epidemic potential of the virus in

314 humans (37). Today, autochthonous CHIK transmission and outbreaks occur in increasingly warmer

315 temperate zones like Europe (38). These two separate arboviral mutations, each responsible for

316 devastating epidemics of global impact, highlight the importance of expanding genomic epidemiology and

317 surveillance of vector-borne pathogens. Furthermore, mNGS recently identified novel vector-borne

318 pathogens including the tick-borne flaviviruses like Alongshan and highly fatal mosquito-borne

319 orthobunyaviruses like Cristoli, Umbre, and others (39-41). These emerging pathogens were identified in

320 high-resource areas where clinical staff had access to mNGS technology. This further highlights the

321 importance of real-time, in-country metagenomic investigation of potential pathogens of concern.

322 Logistical and bureaucratic delays in shipping samples out of a country may translate to the

323 establishment and spread of a pathogen in the interim. 
medRxiv preprint doi: https://doi.org/10.1101/2021.09.25.21262905; this version posted September 28, 2021. The copyright holder for this preprint (which was not certified by peer review) is the author/funder, who has granted medRxiv a license to display the preprint in perpetuity.

All rights reserved. No reuse allowed without permission.

324 To that end, timely contribution of pathogen genomic information from resource-limited settings is critical

325 to the future success of pathogen identification based on genomic sequence data in an increasingly

326 connected world, exemplified by GISAID and GENBANK during the SARS-CoV-2 pandemic (3). The lack

327 of publicly available sequence data of clinically relevant pathogens, such as DENV and CHIK in

328 Southeast Asia, is stark given the regional magnitude of infections by these pathogens.

329 Our mNGS surveillance primarily identified vector-borne pathogens; therefore, our risk models aimed to

330 inform deductive algorithms for undifferentiated fevers in the region. Judicious use of mNGS surveillance

331 would not entail sequencing every undifferentiated fever that is presumed to be dengue. With dengue

332 being the most common diagnosis attributed to fevers in pediatric patients, we aimed to include

333 demographic, behavior, and ecological data that might stratify risk of a vector-borne disease pathogen

334 versus other pathogens in the hospital-based cohort of all ages. Exposure to animals and occupations did

335 not stratify to any risk, but younger age, household car ownership (a surrogate of socioeconomic status)

336 and absence of larvicide use led to increased risk of vector-borne diseases. Advances in land cover

337 analysis now permit disease risk assessment of a population based on their environment. Here, living

338 near surface flooding increased vector-borne disease risk, and surprisingly, DENV cases originated

339 primarily in crop zones that often border urban zones, corroborating previous claims that DENV

340 transmission in Southeast Asia is both rural and urban (42). Even with these tools to aid diagnostic

341 algorithms, it is evident from our data that assigning microbial etiology to undifferentiated fever based on

342 symptoms and demographic data is difficult given the presence of diverse pathogens, the shifting of

343 socioeconomic patterns, and the ongoing transformation of land cover.

344 Limitations in the study included the sampling strategy of sera or whole blood alone, primarily for

345 operational purposes in the early establishment of this pathogen mNGS detection pipeline. To that point,

346 exclusive use of sera contributed to our pathogen detection rate of $40 \%$, likely overestimating vector-

347 borne pathogens to the detriment of respiratory and gastrointestinal pathogens. Since completion of the

348 data analysis presented here, our mNGS monitoring efforts now include nasopharyngeal swabs in

349 addition to ongoing blood sampling. To date, the addition of nasopharyngeal sampling to our mNGS

350 surveillance study has led to timely recovery of entire SARS-CoV-2 genomes, with and without

351 enrichment, for variant identification $(43,44)$. Fortunately, genome recovery of most viruses was 
medRxiv preprint doi: https://doi.org/10.1101/2021.09.25.21262905; this version posted September 28, 2021. The copyright holder for this preprint (which was not certified by peer review) is the author/funder, who has granted medRxiv a license to display the preprint in perpetuity. All rights reserved. No reuse allowed without permission.

352 straightforward from sera, but sampling limitations remain for other taxa; for example, the optimal sample

353 type to identify and speciate Rickettsiae is buffy coat, as opposed to sera, because the bacteria are

354 intracellular (45). Other challenges included identification of less abundant bacterial pathogens,

355 attributable to limited coverage offered by the iSeq, variable host contamination, different library

356 preparation (e.g. DNA-based instead of RNA-based), and again, sample type. The cross-sectional study

357 design limited our ability to see if a patient's clinical course evolved over a longer period of time, and the

358 lack of blood culture capabilities at this hospital did not allow comparison of mNGS to standard diagnostic

359 techniques for bacterial pathogen identification. However, we strived for actionable data, from either a

360 clinical or public health standpoint, and succeeded in cases of Plasmodium spp., HIV, CHIK, and other

361 pathogens. The cost of sequencing is declining while the efficiency of sequencing workflows is increasing,

362 but mNGS analysis of pathogens is still more expensive than targeted diagnostics like PCR or culture (1).

363 Until now, the majority of sequencing and analysis of biological samples collected in Cambodia and other

364 resource-limited settings was outsourced to the Global North. To overcome challenges in reagent

365 procurement, internet connectivity, and lack of advanced bioinformatics training, we built a robust

366 infrastructure to mitigate these issues while also relying upon a pre-curated, rapid bioinformatics pipeline

367 to build in-country expertise that allowed the entire sample collection, processing, and mNGS analysis to

368 happen in a public Cambodian laboratory.

369 As a result, our ongoing, in-country metagenomic sequencing pipeline and capacity-building provides

370 continuous monitoring of common and emerging pathogens for actionable interventions when possible.

371 While the world looks to bolster real-time, genomics-informed pathogen surveillance networks to monitor

372 COVID-19 variants and other emerging pathogens, challenges remain to establish critical "nodes" in

373 biodiverse, resource-scarce areas $(3,46)$. Yet, as shown here, mNGS pathogen surveillance in these

374 settings is feasible, revealing of diverse microbial landscapes, and paramount to the future of global

375 health security.

376

377 MATERIALS AND METHODS

378 Enrollment 
medRxiv preprint doi: https://doi.org/10.1101/2021.09.25.21262905; this version posted September 28, 2021. The copyright holder for this preprint (which was not certified by peer review) is the author/funder, who has granted medRxiv a license to display the preprint in perpetuity. All rights reserved. No reuse allowed without permission.

379 Participants living in Kampong Speu province, Cambodia, were eligible for enrollment in: 1) a longitudinal, 380 community-based cohort of children, two to nine years of age (referred to as "community" and considered 381 semi-active surveillance because study participants were told to notify study coordinator when they have

382 a fever, called a "sick visit" that was considered nested cross-sectional timepoint within the longitudinal 383 cohort); and 2) a cross-sectional hospital-based febrile cohort established in July 2019 (referred to as

384 "hospital" and considered passive surveillance because patients first presented to the hospital with fever 385 and were then asked to participate). Overall, participants were required to 1) be 6 months to 65 years of 386 age; and 2) have a measured fever equal to or greater than $38^{\circ} \mathrm{C}$ in previous 24 hours (see

387 clinicaltrials.gov for full criteria). Demographics, clinical, and risk factor data was stored in a REDCAP®

388 database. Locational data was collected using Garmin® GPS devices and Google Earth.

389 Sample collection and Nucleic Acid Extraction

390 At enrollment, approximately $5 \mathrm{ml}$ of whole blood was collected (except $2 \mathrm{ml}$ collected from those under 2 391 years old). Sera was isolated and stored in cryovials with an equal volume of 2x DNA/RNA Shield (Zymo

392 Research, Irvine, CA) at $-20^{\circ} \mathrm{C}$ and transported from the Kampong Speu Hospital laboratory to the

393 Cambodian National Center for Parasitology Entomology and Malaria Control (CNM) in Phnom Penh,

394 Cambodia. Pathogen RNA was isolated from sera using Quick-RNA MicroPrep Kit (Zymo Research,

395 Irvine, CA) and DNAse-treated.

396 Library Preparation

397 mNGS libraries were prepared from isolated pathogen RNA and converted to cDNA Illumina libraries 398 using the NEBNext Ultra II RNA Library Prep Kit (New England BioLabs, Ipswich, MA). Human rRNA was 399 depleted via FastSelect -rRNA HMR (Qiagen, Germantown, MD). ERCC Spike-In Controls

400 (ThermoFisher, Waltham, MA) were used to indicate potential library preparation errors and to calculate 401 input RNA mass. The initial samples $(n=208)$ were sequenced on a NovaSeq6000 (Illumina, San Diego, 402 CA) instrument as part of a pilot wet lab training at the Chan Zuckerberg BioHub in San Francisco, CA, 403 and then the remainder of the study ( $n=279)$ was performed on an iSeq100 (Illumina) in Phnom Penh, 404 Cambodia, using 150 nucleotide paired-end sequencing. Water controls were included in each library 405 preparation.

406 Bioinformatic analysis 
medRxiv preprint doi: https://doi.org/10.1101/2021.09.25.21262905; this version posted September 28, 2021. The copyright holder for this preprint (which was not certified by peer review) is the author/funder, who has granted medRxiv a license to display the preprint in perpetuity.

All rights reserved. No reuse allowed without permission.

407 Raw fastq files were uploaded to the IDseq portal, a cloud-based, open-source bioinformatics platform, to 408 identify microbes from metagenomic data (https://idseq.net).(18) Potential pathogens were distinguished

409 from commensal flora and contaminating microbial sequences from the environment by establishing a Z-

410 score metric based on a background distribution derived from 16 non-template control libraries. Data

411 were normalized to unique reads mapped per million input reads for each microbe at both species and

412 genus levels. Taxa with Z-score less than 1, an average base pair alignment of less than 50 base pairs,

413 an e-score less than $1 \mathrm{e}-10$ and reads per million (rpM) less than 10 were removed from analysis.

414 Clinical validation

415 Pathogens for which clinical testing capabilities were available in-country were validated to include RT-

416 PCR of Hepatitis B, Plasmodium spp., DENV, CHIK and ZIKV, serology of Human immunodeficiency

417 virus (HIV) 1/2 antibodies or blood smear examination of Plasmodium infections by World Health

418 Organization (WHO)-certified microscopists. Validation testing for other pathogens is underway or being

419 developed. Samples were considered to have 'no pathogen hit' if they meet QA/QC standards but no

420 resulting pathogenic organisms were identified with appropriate thresholds in place.

421 Spatial and environmental data

422 Land cover data for Cambodia were downloaded from Open Development Cambodia

423 (https://opendevelopmentcambodia.net). The data come from the Regional Land Cover Monitoring

424 System at a resolution of $30 \mathrm{~m}$ by $30 \mathrm{~m}$ and were from 2016 (the most recent year we could find at this

425 resolution). We used open-source satellite imagery (Google Earth) to ensure that the land cover data

426 matched the reality on the ground. Participant village locations were then plotted on top of the land cover

427 map. To summarize and quantify land cover types, we created $1 \mathrm{~km}$ buffers around the geographic

428 coordinates for participant villages and extracted land cover characteristics for each participant using the

429 Zonal Histogram function in QGIS (version 3.16.5: https://qgis.org). We then categorized each participant

430 according to the land cover type that predominated around their village location, and tabulated land cover

431 types according to disease outcomes. Environmental indices (EI) for surface water and vegetation were

432 extracted from Moderate Resolution Imaging Spectroradiometer (MODIS) products

433 (MOD13Q1/MYD13Q1 250 meter AQUA/TERRA 16-day composites). A normalized flooding index

434 (NDFI), the normalized differential vegetation index (NDVI), and the enhanced vegetation index (EVI) 
medRxiv preprint doi: https://doi.org/10.1101/2021.09.25.21262905; this version posted September 28, 2021. The copyright holder for this preprint (which was not certified by peer review) is the author/funder, who has granted medRxiv a license to display the preprint in perpetuity.

All rights reserved. No reuse allowed without permission.

435 were all extracted for this analysis.(19)(20) NDFI gives an indication of surface water, NDVI gives an

436 indication of surface vegetation, and EVI is an improvement on NDVI in that it is less sensitive to

437 atmospheric conditions and forest canopies. The data were downloaded for each 16-day time interval

438 (from July 2018-May 2020) using a 1km buffer around the home of each patient in the dataset. The visit

439 date of each participant was then used to align the El values for each participant. El values from the 16-

440 day period leading up to a participant visit were used for analyses.

441 Statistical analysis

442 The primary endpoint is identification of pathogen sequences via IDseq analysis in serum samples from

443 febrile individuals treated at the Kampong Speu District Referral Hospital. On average, we found 25-40\%

444 of the monthly febrile cases were attributable to vector-borne disease. As such, we decided to determine

445 which demographic variables, risk factors, and climate data were associated with vector-borne pathogen

446 identification using a Bayesian logistic regression model. For our feature coefficients, we used a weakly

447 informative prior and a MCMC sampler to determine the posterior distribution of the coefficients. We plot

448 the marginal coefficient densities and display the posterior medians along with $95 \%$ credible intervals.

449 We fit two separate models: one for the hospital cohort and one for the community cohort. Most, but not

450 all, features are present in both models. More details about variable selection, model diagnostics, and

451 model sensitivity may be found in the supplemental material.

452 Data Availability

453 All genome sequence data from this study have been submitted to the NCBI Sequence Read Archive

454 under Bioproject ID PRJNA681566. All protocols are uploaded on protocols.io and all bioinformatics code

455 is available on https://github.com.

456 Ethics

457 The study protocol was approved by the institutional review boards at the US National Institutes of Health

458 and the National Ethics Committee on Human Research in Cambodia (NCT04034264 and NCT03534245

459 on clinicaltrials.gov). All individuals provided informed consent. The guardians of all pediatric participants

460 provided signed informed consent to participate in the study; and those aged $14-17$ also provided

461 assent in addition to parental consent.

\section{Acknowledgements}


medRxiv preprint doi: https://doi.org/10.1101/2021.09.25.21262905; this version posted September 28, 2021. The copyright holder for this preprint (which was not certified by peer review) is the author/funder, who has granted medRxiv a license to display the preprint in perpetuity. All rights reserved. No reuse allowed without permission.

463 We thank patients and families of Kampong Speu District Referral Hospital who participated in this study.

464 We thank the Provincial Health Department of Kampong Speu province in Cambodia. We thank all the

465 other employees at the Chan Zuckerberg Biohub and Chan Zuckerberg Initiative not listed in the author

466 byline. We thank Brian Moyer and the NIAID Office of Cyberinfrastructure and Computational Biology

467 (OCICB) for their assistance in improving the cyberinfrastructure of our Cambodian field sites.

468 Funding

469 This research is supported by the Division of Intramural Research at the National Institute of Allergy and 470 Infectious Diseases at the National Institutes of Health and the Bill and Melinda Gates Foundation [grant 471 number OPP1211806]. The authors declare no competing interests.

\section{References}

474

1. G. L. Armstrong, et al., Pathogen Genomics in Public Health. N. Engl. J. Med. 381, 2569-2580 (2019).

2. X. Deng, et al., Metagenomic sequencing with spiked primer enrichment for viral diagnostics and genomic surveillance. Nat. Microbiol., 1-12 (2020).

3. J. L. Gardy, N. J. Loman, Towards a genomics-informed, real-time, global pathogen surveillance system. Nat. Rev. Genet. 19, 9-20 (2018).

4. R. C. Christofferson, et al., Current vector research challenges in the greater Mekong subregion for dengue, Malaria, and Other Vector-Borne Diseases: A report from a multisectoral workshop March 2019. PLoS Negl. Trop. Dis. 14, e0008302 (2020).

5. T. C. Mueller, et al., Acute undifferentiated febrile illness in rural Cambodia: a 3-year prospective observational study. PloS One 9, e95868 (2014).

6. C.M. Farris et al. Rickettsial Disease: Important causes of undifferentiated Fever in Cambodia. 9th Tick Tick-Borne Pathog Conf Asia Pac Rickettsia Conf 2017;Cairns, Australia.

7. P. Parola, D. Musso, D. Raoult, Rickettsia felis: the next mosquito-borne outbreak? Lancet Infect. Dis. 16, 1112-1113 (2016).

8. D. Prasetyo et al. Bartonellosis in Cambodia and Lao People's Democratic Republic.9th Tick TickBorne Pathog Conf Asia Pac Rickettsia Conf 2017; Cairns, Australia.

9. S. Boyer, S. Marcombe, S. Yean, D. Fontenille, High diversity of mosquito vectors in Cambodian primary schools and consequences for arbovirus transmission. PLOS ONE 15, e0233669 (2020).

10. J.-M. Reynes, et al., Nipah Virus in Lyle's Flying Foxes, Cambodia. Emerg. Infect. Dis. 11, 10421047 (2005). 
medRxiv preprint doi: https://doi.org/10.1101/2021.09.25.21262905; this version posted September 28, 2021. The copyright holder for this preprint (which was not certified by peer review) is the author/funder, who has granted medRxiv a license to display the preprint in perpetuity. All rights reserved. No reuse allowed without permission.

11. Y. E. Raji, O. P. Toung, N. M. Taib, Z. B. Sekawi, A systematic review of the epidemiology of Hepatitis E virus infection in South - Eastern Asia. Virulence 12, 114-129 (2021).

12. H. Auerswald, et al., Serological Evidence for Japanese Encephalitis and West Nile Virus Infections in Domestic Birds in Cambodia. Front. Vet. Sci. 7 (2020).

13. M. R. Wilson, et al., Clinical Metagenomic Sequencing for Diagnosis of Meningitis and Encephalitis. N. Engl. J. Med. 380, 2327-2340 (2019).

14. W. Gu, S. Miller, C. Y. Chiu, Clinical Metagenomic Next-Generation Sequencing for Pathogen Detection. Annu. Rev. Pathol. 14, 319-338 (2019).

15. T. Doan, et al., Illuminating uveitis: metagenomic deep sequencing identifies common and rare pathogens. Genome Med. 8, 90 (2016).

16. A. Ramesh, et al., Metagenomic next-generation sequencing of samples from pediatric febrile illness in Tororo, Uganda. PLOS ONE 14, e0218318 (2019).

17. S. Saha, et al., Unbiased Metagenomic Sequencing for Pediatric Meningitis in Bangladesh Reveals Neuroinvasive Chikungunya Virus Outbreak and Other Unrealized Pathogens. mBio 10 (2019).

18. K. L. Kalantar, et al., IDseq-An open source cloud-based pipeline and analysis service for metagenomic pathogen detection and monitoring. GigaScience 9 (2020).

19. Rouse J, Hass R, Monitoring the vernal advancement and retrogradation (Green wave effect) of natural vegetation. NASA-CR-139243 Report No.: E74-10676, 8-9 (1974).

20. M. Boschetti, F. Nutini, G. Manfron, P. A. Brivio, A. Nelson, Comparative Analysis of Normalised Difference Spectral Indices Derived from MODIS for Detecting Surface Water in Flooded Rice Cropping Systems. PLOS ONE 9, e88741 (2014).

21. M. Mayxay, et al., Causes of non-malarial fever in Laos: a prospective study. Lancet Glob. Health 1, e46-e54 (2013).

22. S. D. Blacksell, et al., Genetic typing of the 56-kDa type-specific antigen gene of contemporary Orientia tsutsugamushi isolates causing human scrub typhus at two sites in north-eastern and western Thailand. FEMS Immunol. Med. Microbiol. 52, 335-342 (2008).

23. V. O. D. English, Chikungunya Spreads to 21 Provinces, Almost 6,000 Suspected Infected. Cambodia Dly. (2020) (March 16, 2021).

24. K. Ruchusatsawat, et al., Long-term circulation of Zika virus in Thailand: an observational study. Lancet Infect. Dis. 19, 439-446 (2019).

25. V. Duong, et al., Low Circulation of Zika Virus, Cambodia, 2007-2016. Emerg. Infect. Dis. 23, 296299 (2017).

26. V. Heang, et al., Zika Virus Infection, Cambodia, 2010. Emerg. Infect. Dis. 18, 349-351 (2012).

27. T. Wongsurawat, et al., Case of Microcephaly after Congenital Infection with Asian Lineage Zika Virus, Thailand. Emerg. Infect. Dis. 24 (2018).

28. D. Tongthainan, et al., Seroprevalence of Dengue, Zika, and Chikungunya Viruses in Wild Monkeys in Thailand. Am. J. Trop. Med. Hyg. 103, 1228-1233 (2020). 
medRxiv preprint doi: https://doi.org/10.1101/2021.09.25.21262905; this version posted September 28, 2021. The copyright holder for this preprint (which was not certified by peer review) is the author/funder, who has granted medRxiv a license to display the preprint in perpetuity. All rights reserved. No reuse allowed without permission.

533 29. S. Siv, et al., Plasmodium vivax Malaria in Cambodia. Am. J. Trop. Med. Hyg. 95, 97-107 (2016).

534 30. S. Hem, et al., Estimating the Burden of Leptospirosis among Febrile Subjects Aged below 20 Years in Kampong Cham Communities, Cambodia, 2007-2009. PLoS ONE 11 (2016).

31. H. Liao, et al., Phylodynamic analysis of the dissemination of HIV-1 CRF01_AE in Vietnam. Virology 391, 51-56 (2009).

32. L. N. Chhong, et al., Prevalence and clinical manifestations of dengue in older patients in Bangkok Hospital for Tropical Diseases, Thailand. Trans. R. Soc. Trop. Med. Hyg. 114, 674-681 (2020).

33. M. R. Kasper, et al., Infectious Etiologies of Acute Febrile Illness among Patients Seeking Health Care in South-Central Cambodia. Am. J. Trop. Med. Hyg. 86, 246-253 (2012).

34. K. Chheng, et al., A Prospective Study of the Causes of Febrile Illness Requiring Hospitalization in Children in Cambodia. PLOS ONE 8, e60634 (2013).

35. Cambodian Ministry of Health, National strategic plan for elimination of malaria in the Kingdom of Cambodia 2011-2025.

36. Y. Liu, et al., Evolutionary enhancement of Zika virus infectivity in Aedes aegypti mosquitoes. Nature

37. K. A. Tsetsarkin, D. L. Vanlandingham, C. E. McGee, S. Higgs, A Single Mutation in Chikungunya 545, 482-486 (2017). Virus Affects Vector Specificity and Epidemic Potential. PLOS Pathog. 3, e201 (2007).

38. F. Jourdain, et al., From importation to autochthonous transmission: Drivers of chikungunya and

39. C. Rodriguez, et al., Fatal Encephalitis Caused by Cristoli Virus, an Emerging Orthobunyavirus, dengue emergence in a temperate area. PLoS Negl. Trop. Dis. 14, e0008320 (2020).

40. Z.-D. Wang, et al., A New Segmented Virus Associated with Human Febrile Illness in China. N. Engl.

41. P. Pérot, et al., Identification of Umbre Orthobunyavirus as a Novel Zoonotic Virus Responsible for Lethal Encephalitis in 2 French Patients with Hypogammaglobulinemia. Clin. Infect. Dis. 72, 17011708 (2021).

42. N. T. T. Pham, C. T. Nguyen, H. H. Vu, Assessing and modelling vulnerability to dengue in the Mekong Delta of Vietnam by geospatial and time-series approaches. Environ. Res. 186, 109545 (2020).

43. Manning JE et al, Rapid metagenomic characterization of a case of imported COVID-19 in

566 45. M. T. Robinson, J. Satjanadumrong, T. Hughes, J. Stenos, S. D. Blacksell, Diagnosis of spotted fever

44. , Severe acute respiratory syndrome coronavirus 2 isolate SARS-CoV-2/human/KHM/B117/2021, complete genome (2021) (June 9, 2021).

568 46. , PM announces plan for 'Global Pandemic Radar.' GOV.UK (May 24, 2021). 